\title{
Aplikasi Radar Cuaca untuk Identifikasi Fluktuasi Kondisi Cuaca Ekstrim
}

\author{
Budi Prasetyo*, ${ }^{1}$ Nikita Pusparini, ${ }^{1}$ Irwandi, ${ }^{1}$ dan Welly Fitria ${ }^{2}$ \\ ${ }^{1}$ Badan Meteorologi, Klimatologi, dan Geofisika \\ ${ }^{2}$ Fakultas Matematika dan Ilmu Pengetahuan Alam, Universitas Syiah Kuala,Banda Aceh
}

Intisari

\begin{abstract}
Radar (Radio Detection and Ranging) cuaca dapat digunakan sebagai alat deteksi, analisis, maupun prediksi kondisi cuaca. Dalam penelitian ini dibahas analisis perubahan kondisi cuaca pada kejadian banjir di Kota Medan pada tanggal 05 Oktober 2018. Data radar cuaca Enterprise Electronics Corporation (EEC) selama 24 jam mulai pk. 07.00 WIB, tanggal 5 hingga 6 Oktober 2018 digunakan pada penelitian ini. Data diperoleh dari Balai Besar Meteorologi Klimatologi dan Geofisika Wilayah I dalam format volumetric (.vol) dan memiliki selang waktu per 10 menit. Metode yang digunakan yaitu analisis deskriptif hasil produk turunan yang diolah menggunakan perangkat lunak Enterprise Doppler Graphic Environment (EDGE) berupa Coloumn Maximum (CMAX), momen intensitas horizontal, momen rata-rata curah hujan, dan Vertical Integrated Reflectivity (VIR), serta grafik curah hujan (RHG). Hasil penelitian menunjukkan bahwa fluktuasi kondisi cuaca yang terjadi sangat tinggi. Secara umum, curah hujan intensitas tinggi yang terjadi terbagi menjadi tiga periode, yaitu hujan pada siang hingga sore (pukul 14.00-15.50 WIB), petang (pukul 18.20-19.40 WIB), dan malam hari (21.10-23.40 WIB). Fluktuasi tertinggi terjadi pada periode pertama dengan kenaikan curah hujan tertinggi terjadi di Kecamatan Medan Helvetia; pada periode kedua terjadi di Kecamatan Medan Kota; dan periode ketiga terjadi di Kecamatan Medan Johor.
\end{abstract}

\begin{abstract}
Weather radar (Radio Detection and Ranging) can be used as a means of detecting, analyzing, and predicting weather conditions. In the study discussed the analysis of changes in weather conditions in the event of flooding in Medan City on October 5, 2018. Enterprise Electronics Corporation (EEC) weather radar data for 24 hours starting pk. 07.00 WIB, 5 to 6 October 2018 was used in this study. Data were obtained from the Center for Meteorology, Climatology and Geophysics Region I in volumetric (.vol) format and has an interval of 10 minutes. The method used is a descriptive analysis of derivative products processed using Enterprise Doppler Graphic Environment (EDGE) software in the form of Column Maximum (CMAX), moments of horizontal intensity, moments of average rainfall, and Vertical Integrated Reflectivity (VIR), and bulk charts rain (RHG). The results showed that the fluctuations in weather conditions that occurred were very high. In general, highintensity rainfall that occurs is divided into three periods, namely rain from afternoon to evening (14.00 - 15.50 WIB), evening (18.20 - 19.40 WIB), and night (21.10 - 23.40 WIB). The highest fluctuation occurred in the first period with the highest increase in rainfall occurring in Medan Helvetia District; the second period occurred in Medan Kota District, and the third period occurred in Medan Johor District.
\end{abstract}

Keywords: flood; Medan City; rainfall; weather radar.

*Corresponding author: bo3di.kecil@gmail.com

http://dx.doi.org/10.12962/j24604682.v16i3.5155

2460-4682 (C)Departemen Fisika, FSAD-ITS

\section{PENDAHULUAN}

Posisi wilayah Indonesia yang berada di wilayah tropis menyebabkan Indonesia memiliki curah hujan yang cukup tinggi, salah satunya yaitu Kota Medan. Kota terbesar di Sumatera ini merupakan ibukota Sumatra Utara yang berada di sekitar daerah khatulistiwa yang memiliki curah hujan cukup tinggi sepanjang tahun. Hal ini menyebabkan wilayah ini rentan terjadi bencana yang dapat diakibatkan oleh curah hujan tinggi seperti banjir. Berdasarkan Data Informasi Bencana
Indonesia (DIBI) dari Badan Nasional Penanggulangan Bencana (BNPB) (2018), Kota Medan mengalami banjir sebanyak 427 kali dari periode 20022018 [1]. Dengan kata lain, setiap tahun terjadi 25 kali banjir di wilayah ini.

Banjir merupakan salah satu bencana hidrometeorologis yang diakibatkan oleh tingginya curah hujan. Badan Meteorologi Klimatologi dan Geofisika (BMKG) mengklasifikasikan intensitas curah hujan menjadi 4 tipe yaitu: curah hujan ringan $(1-5 \mathrm{~mm} / \mathrm{jam}$ atau $5-20 \mathrm{~mm} / \mathrm{hari}$, sedang $(5-10$ $\mathrm{mm} / \mathrm{jam}$ atau $20-50 \mathrm{~mm} / \mathrm{hari})$, lebat $(10-20 \mathrm{~mm} / \mathrm{jam}$ atau $50-$ $100 \mathrm{~mm} / \mathrm{hari})$, dan sangat lebat/ekstrim $(>20 \mathrm{~mm} / \mathrm{jam}$ atau 


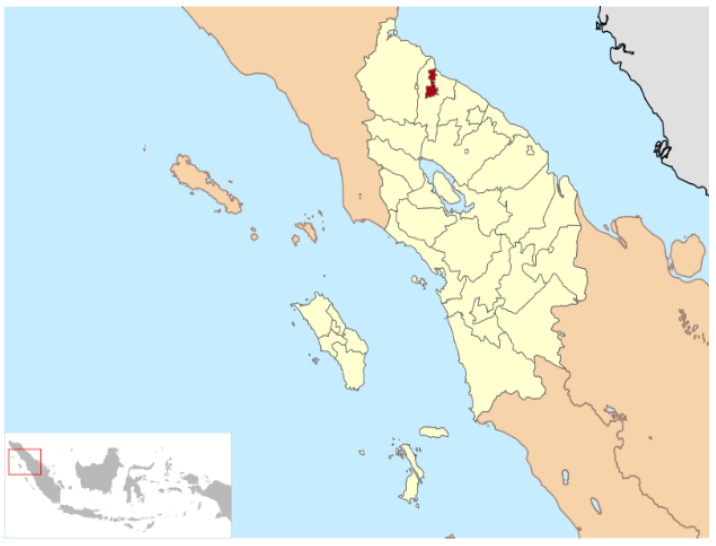

(a) Wilayah Kota Medan

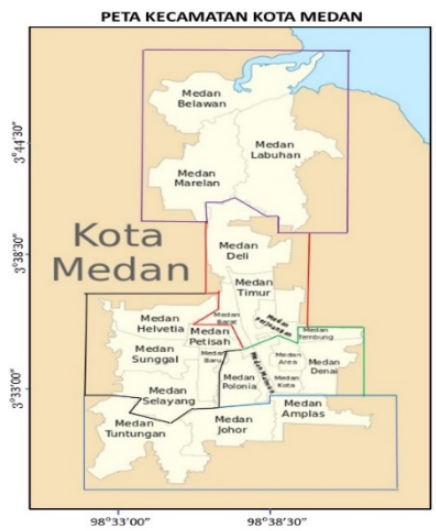

(b) Peta Kecamatan Kota Medan

Gambar 1: (a) Lokasi wilayah Kota Medan (warna merah) di wilayah Provinsi Sumut. Insert lokasi Sumut (kotak merah) dalam wilayah Indonesia, (b) Peta Kecamatan Kota Medan; garis merupakan pembagian wilayah Kota Medan; Garis Ungu: Wilayah Medan Bagian Utara, Garis Merah: Medan Bagian tengah, Garis Hijau: Medan Bagian Timur, Garis Hitam: Medan Bagian Barat, dan Garis Biru: Medan Bagian Selatan [16].

$>100 \mathrm{~mm} / \mathrm{hari}$ ) [2]. Curah hujan ekstrim yang melanda Kota Medan pada tanggal 5 Oktober 2018 menyebabkan Kota Medan dan sekitarnya dilanda banjir. Intensitas curah hujan yang cukup tinggi menyebabkan debit air di sejumlah Daerah Aliran Sungai (DAS) meningkat sehingga sebagian wilayah Kota Medan terkena banjir. Curah hujan ekstrim sangat berkaitan dengan intensitas dan pengukuran curah hujan, selain itu juga terkait dengan pergerakan awan-awan konvektif [3]. Pengukuran curah hujan secara langsung dilakukan menggunakan penakar curah hujan dan pendeteksian kehadiran awan melalui pengamatan secara langsung yang ditandai dengan kondisi awan menjulang tinggi berwarna hitam dan biasanya disertai kilat/petir dan angin kencang. Di sisi lain, pendeteksian secara tidak langsung dapat dilakukan menggunakan Radar cuaca. Pengukuran curah hujan dan pergerakan awan-awan konvektif oleh Radar cuaca dilakukan melalui estimasi ukuran butiran-butiran air dalam jarak dan ketinggian tertentu.

Radar cuaca merupakan salah satu alat meteorologi yang dapat membantu mengamati cuaca secara khusus. Radar cuaca mampu mendeteksi adanya pertumbuhan sel-sel konvektif mulai dari fase pertumbuhan, tahap matang, hingga fase punah [4]. Radar menggunakan pantulan gelombang (echo) hasil dari pemindaian beberapa level untuk mendeteksi awan dan pergerakannya, sebaran dan intensitas hujan, kecepatan arah dan angin, dan badai guntur [5,6].

Penggunaan Radar telah dilakukan oleh para meteorologis dan peneliti dari berbagai belahan dunia dalam menganalisis maupun memperkirakan cuaca. Contohnya di Korea Selatan dimana para meteorologis dan peneliti menggunakan Radar cuaca dalam menganalisis dan prediksi kejadian banjir [6]. Di Indonesia, Radar cuaca juga digunakan untuk pengamatan awan dan variasi cuaca $[7,8)$, analisis cuaca ekstrim seperti hujan es [3,9], curah hujan ekstrim [10], prediksi cuaca jangka pendek (nowcasting) dan peringatan dini [11]. Perkembangan penggunaan Radar di wilayah Indonesia juga semakin pe- sat. BMKG telah membangun dan memasang 27 Radar cuaca pada lokasi yang tersebar di seluruh Indonesia. Pemasangan Radar cuaca yang tersebar dari Aceh sampai Merauke tersebut telah dilakukan hingga tahun 2014, salah satunya di Kota Medan [12].

Perubahan kondisi cuaca, sangat cepat terjadi dan juga bersifat lokal. Hasil pengamatan menggunakan Radar cuaca lebih rinci tetapi cakupannya lebih sempit [13]. Semakin dekat lokasi Radar maka semakin bagus hasil yang di peroleh. Selain itu juga Radar memiliki resolusi waktu yang cukup bagus yaitu 10 menitan. Sehingga perubahan cuaca dalam skala lokal (kecil) dan dalam durasi singkat dapat diketahui. Oleh karena itu, penelitian ini akan membahas perubahan kondisi cuaca dalam skala lokal (perkecamatan) menggunakan data Radar cuaca dengan mengambil studi kasus kejadian banjir di Kota Medan dan sekitarnya pada tanggal 5 Oktober 2018.

\section{METODOLOGI}

Wilayah penelitian ini difokuskan pada wilayah Kota Medan dengan koordinat $3^{\circ} 30^{\prime}-3^{\circ} 43^{\prime}$ LU dan $98^{\circ} 35^{\prime}-98^{\circ} 44^{\prime}$ BT. Kota Medan memiliki luas $265,10 \mathrm{~km}^{2}$ (3,6\% dari keseluruhan luas Sumut) yang berbatasan langsung dengan Kabupaten Deli Serdang di sebelah Selatan, Timur, dan Barat, serta berbatasan dengan Selat Malaka di sebelah Utara [14] (Gambar 1(a)). Kota Medan terdiri dari 21 Kecamatan yang tersebar di seluruh wilayah Kota Medan [15] (Gambar 1(b)).

Data yang digunakan adalah data Radar cuaca Enterprise Electronics Corporation (EEC) yang memiliki resolusi temporal per 10 menit. Data tersebut memiliki format volumetric (.vol) yang diperoleh dari Balai Besar MKG wilayah 1 Medan. Radar cuaca ini merupakan salah satu radar cuaca yang dimiliki BMKG bertipe C-band yang beroperasi pada Band 56005650MHz. BMKG menggunakan Radar cuaca tersebut seba- 
TABEL I: Posisi koordinat titik curah hujan di tiap kecamatan [14].

\begin{tabular}{|c|c|c|c|c|c|c|}
\hline No & Kecamatan & Luas & Persentase $(\%)$ & Lintang & Bujur & Wilayah \\
\hline 1 & Medan Tuntungan & 20,68 & 7,8 & 3,52691 & 98,614704 & \\
\hline 2 & Medan Johor & 14,58 & 5,5 & 3,531957 & 98,673043 & Medan Bagian Selatan \\
\hline 3 & Medan Amplas & 11,19 & 4,22 & 3,542345 & 98,711816 & \\
\hline 4 & Medan Denai & 9,05 & 3,41 & 3,578109 & 98,72047 & \\
\hline 5 & Medan Area & 4,52 & 2,08 & 3,580788 & 98,700548 & \\
\hline 6 & Medan Kota & 5,27 & 1,99 & 3,561348 & 98,699537 & Medan Bagian Timur \\
\hline 7 & Medan Maimun & 2,98 & 1,13 & 3,574949 & 98,678766 & \\
\hline 8 & Medan Polonia & 9,01 & 3,40 & 3,563118 & 98,672137 & \\
\hline 9 & Medan Tembung & 7,99 & 3,01 & 3,595067 & 98,722731 & \\
\hline 10 & Medan Baru & 5,84 & 2,2 & 3,564271 & 98,659542 & \\
\hline 11 & Medan Selayang & 12,81 & 4,83 & 3,555649 & 98,631396 & \\
\hline 12 & Medan Sunggal & 15,44 & 5,83 & 3,582075 & 98,62817 & Medan Bagian Barat \\
\hline 13 & Medan Helvetia & 13,16 & 4,97 & 3,604495 & 98,628083 & \\
\hline 14 & Medan Petisah & 6,82 & 2,57 & 3,592111 & 98,660258 & \\
\hline 15 & Medan Barat & 5,33 & 2,01 & 3,612066 & 98,670158 & \\
\hline 16 & Medan Timur & 7,76 & 2,93 & 3,624557 & 98,681391 & Medan Bagian Tengah \\
\hline 17 & Medan Perjuangan & 4,09 & 1,54 & 3,609977 & 98,689242 & \\
\hline 18 & Medan Deli & 20,84 & 7,86 & 3,660333 & 98,668902 & \\
\hline 19 & Medan Labuhan & 36,67 & 13,83 & 3,723087 & 98,6934 & \\
\hline 20 & Medan Marelan & 23,82 & 8,9 & 3,707672 & 98,651283 & Medan Bagian Utara \\
\hline 21 & Medan Belawan & 26,25 & 9,9 & 3,760804 & 98,674519 & \\
\hline
\end{tabular}

gai penunjang sistem peringatan dini meteorologi, Meteorology Early Warning System (MEWS), yang bertujuan mengurangi dampak kerugian materi dan jiwa akibat cuaca ekstrem [12]. Radar ini menerapkan efek Doppler yang dapat mengukur reflektivitas, kecepatan radial, dan lebar spektral dari suatu objek. Produk data yang dapat diperoleh antara lain histogram curah hujan, Wind Shear, deteksi Siklon tropis skala meso.

Metode yang digunakan pada penelitian ini difokuskan pada hasil intrepretasi citra Radar. Data citra Radar cuaca berdasarkan pantulan kembali oleh butiran-butiran air di awan dan digambarkan dalam bentuk reflektivitas. Semakin besar energi pantul yang diterima oleh Radar, semakin besar juga nilai reflektifitas dan semakin besar juga intensitas hujan yang terjadi [11]. Perangkat lunak Enterprise Doppler Graphic Environment (EDGE) digunakan untuk mengolah data Radar volumetric (.vol) menjadi beragam produk seperti Coloumn Maximum (CMAX), momen intensitas horizontal dan momen rata-rata hujan, Vertical Integrated Reflectivity (VIR) dan grafik curah hujan, serta Rain History Graph (RHG). Perangkat lunak EDGE berasal dari produsen radar dan memiliki lisensi khusus sehingga perangkat lunak tersebut berada khusus di Balai Besar Meteorologi Klimatologi dan Geofisika Wilayah I Medan. Pemilihan produk tersebut berdasarkan kemudahan dan keakuratan dalam menganalisis kondisi cuaca di suatu wilayah. Hasil produk tersebut ditampilkan dalam bentuk gambar dua dimensi dan khusus untuk RHG berupa grafik deret waktu (Time Series) di beberapa titik.

Aplikasi EDGE dikembangkan untuk menyediakan semua fitur yang dibutuhkan untuk menganalisis maupun memprakirakan cuaca. Aplikasi ini memiliki fitur-fitur yang memudahkan pengguna dalam intrepretasi, menyimpan, membandingkan, menganimasikan, dan mentransfer produk-produk hasil pengolahan citra Radar. Untuk memudahkan dalam menganalisis fluktuasi kondisi cuaca di Kota Medan, kami membagi Kota Medan dalam lima wilayah berdasarkan kecamatan yang saling berdekatan (Gambar 1(b) dan Tabel I).

Produk CMAX merupakan produk yang menampilkan nilai reflektivitas maksimum hingga ketinggian tertentu. Produk ini sangat bermanfaat bagi para meteorologis untuk melihat kondisi terburuk dari keseluruhan lapisan atmosfer tanpa harus membandingkan beberapa gambar dari beberapa lapisan. Pada kajian ini input produk cmax mulai dari ketinggian 0 hingga $30 \mathrm{~km}$. Produk CMAX memiliki besaran satuan desibel (dBZ) untuk momen intensitas horizontal dan satuan $\mathrm{mm} /$ jam untuk momen rata-rata curah hujan.

Produk VIR merupakan jumlah kandungan massa air di atmosfer yang belum jatuh ke bumi sebagai hujan. Produk ini dapat digunakan sebagai alat untuk memprediksi potensi curah hujan dengan intensitas sedang hingga lebat yang akan terjadi di suatu wilayah. Produk VIR memiliki fungsi yang hampir sama dengan produk Vertically Integrated Liquid (VIL), akan tetapi VIR bentuk reflektivitas sehingga dinyatakan dalam satuan dBZ. Semakin tinggi nilai reflektivitas VIR maka semakin besar pula kandungan massa air yang terkandung dalam atmosfer di atas lokasi tersebut.

Produk RHG menghasilkan data curah hujan di suatu titik selama periode tertentu. Grafik yang dihasilkan menunjukkan perubahan curah hujan yang terjadi dalam waktu 10 menit. Analisis RHG dilakukan di setiap kecamatan Kota Medan sehingga dapat diketahui kapan dan dimana terjadi hujan serta besaran intensitasnya. Pembagian titik-titik lokasi pengamatan diwakili oleh satu titik di tiap kecamatan di Kota Medan sehingga terdapat 17 titik pengamatan curah hujan. Lokasi titik-titik tersebut di tampilkan pada Tabel I. 


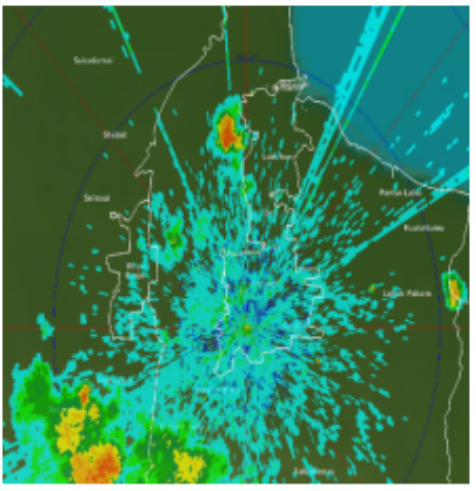

(a)

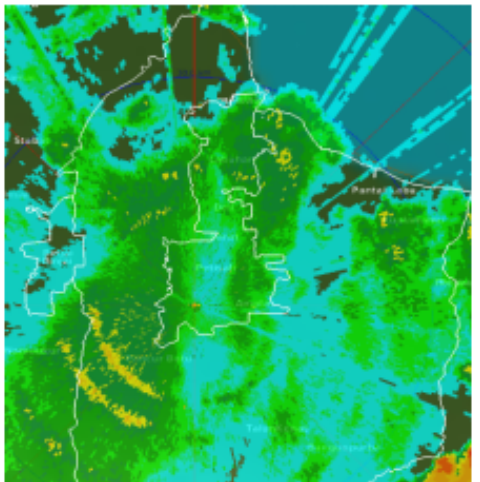

(d)

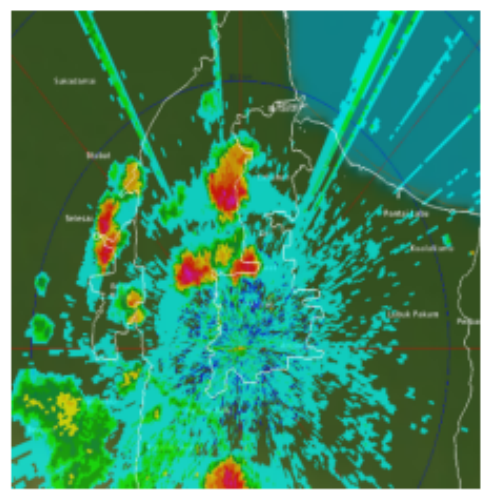

(b)

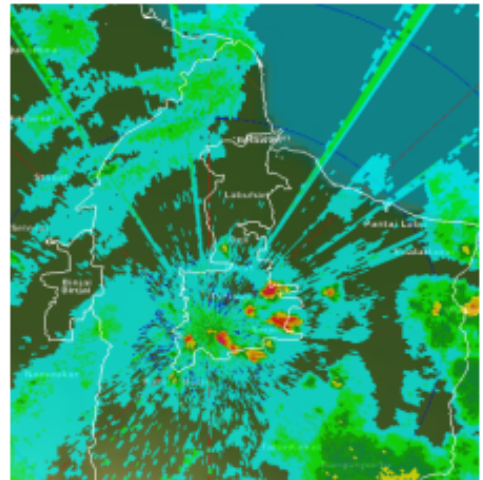

(e)

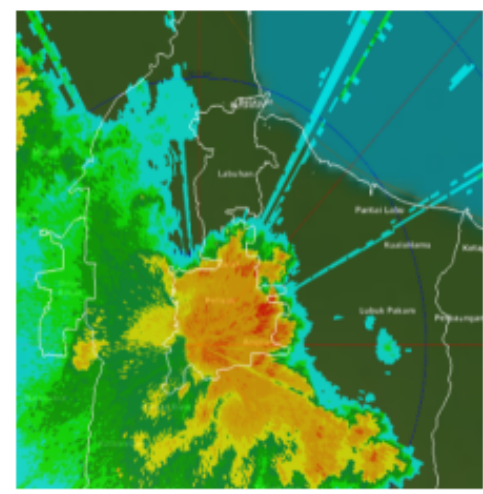

(c)

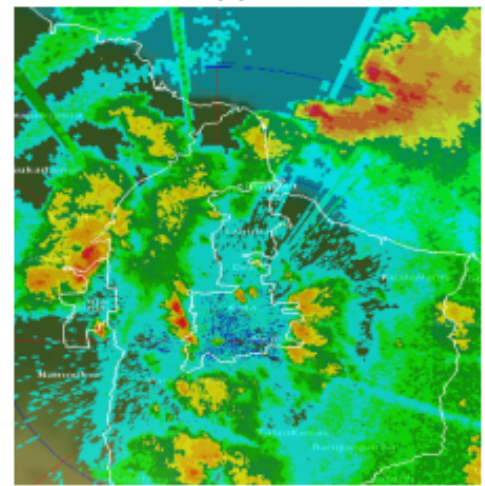

(f)

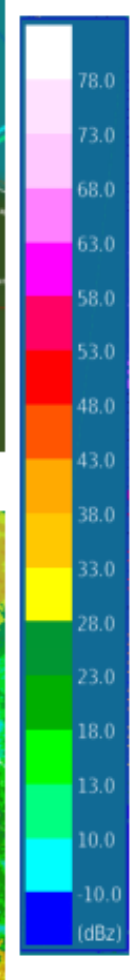

Gambar 2: Hasil Produk CMAX pada pukul (a) 12.30 WIB, (b) 13.00 WIB, (c) 15.00 WIB, (d) 17.00 WIB, (e) 18.10 WIB, dan (f) $20.30 \mathrm{WIB}$.

\section{HASIL DAN PEMBAHASAN}

\section{Analisis hasil produk CMAX}

Berdasarkan visualisasi produk CMAX, terlihat bahwa terdapat reflektifitas yang cukup signifikan (43.0 dBZ) di sebelah Barat Laut Medan pada jam 12.30 WIB (Gambar 2(a)). Reflektivitas tersebut semakin berkembang dan semakin meningkat hingga mencapai 53.0 dBZ pada pukul 13.00 WIB di wilayah Medan Bagian Utara-Tengah-Barat yang berbataan dengan Kabupaten Deli Serdang. Selain itu, pada saat yang bersamaan juga terdapat sel dengan nilai reflektivitas signifikan lain yang tumbuh dan berkembang di wilayah Medan Bagian Barat berbatasan dengan Kabupaten Deli Serdang (Gambar 2(b)). Sel tersebut terus berkembang dan mulai memasuki wilayah Medan Bagian Barat pada pukul 14.00 WIB, sedangkan sel signifikan di Medan Bagian Utara menghilang.

Sel-sel tersebut terus bergerak masuk dan meluas hingga mencakup setengah Kota Medan meliputi Medan Bagian Barat, Medan Bagian Timur, Medan Bagian Selatan, dan sebagian Medan Bagian Tengah dalam waktu satu jam yaitu pukul 15.00 WIB (Gambar 2(c)). Kondisi tersebut bertahan dalam selang waktu 30 menit kemudian reflektivitas menunjukkan penurunan pada nilai berkisar antara 18-33 dBZ, akan tetapi sebaran nilai reflektivitas tersebut semakin meluas hingga mencakup wilayah Medan Bagian Utara sampai pukul 17.00 WIB (Gambar 2(d)).

Wilayah Kota Medan sempat menunjukkan nilai reflektivitas yang tidak signifikan selama kurang lebih satu jam hingga pukul 18.00 WIB. Setelah itu, sel-sel reflektifitas signifikan kembali yang ditandai dengan nilai reflektivitas $53 \mathrm{dBZ}$ terlihat muncul di beberapa titik di wilayah Medan Bagian Timur (Medan Tembung dan Medan Denai), dan Medan Bagian Selatan (Medan Tuntungan) pada pukul 18.10 WIB (Gambar 2(e)). Sel-sel tersebut terus meningkat hingga kembali menutupi sebagian wilayah Kota Medan yaitu Medan Bagian timur, Medan Bagian Tengah dan sebagian Medan Bagian Barat pada pukul 18.30 WIB. Sel-sel tersebut terus bergerak ke arah utara sehingga Wilayah Medan Bagian Utara juga diliputi sel-sel dengan nilai reflektivitas 18-33 dBZ pada pukul 19.30 WIB. Sel-sel tersebut semakin menurun dan menghilang pada pukul 20.00 WIB sehingga untuk beberapa saat Kota Medan kembali normal meskipun beberapa wilayah perbatasan Deli Serdang-Medan Bagian Barat terdapat nilai reflektivitas sginifikan dengan durasi singkat pada pukul 20.30 WIB (Gambar 2(f)).

Nilai reflektivitas signifikan kembali muncul pada pukul 21.10 WIB di perbatasan Deli Serdang - Medan Bagian Selatan-Timur. Sel-sel tersebut terus meluas dan bergerak masuk ke Wilayah Kota Medan sehingga selang waktu satu jam kemudian, sebagian besar Kota Medan diliputi dengan nilai 


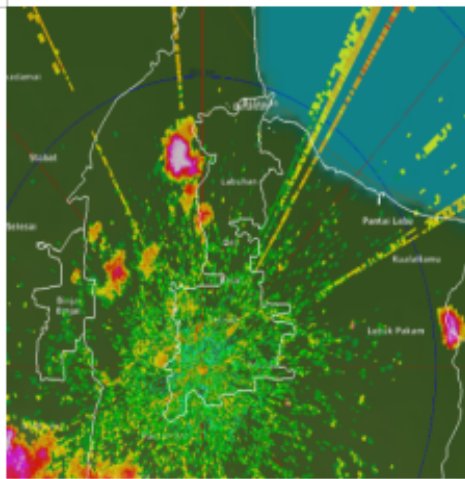

(a)

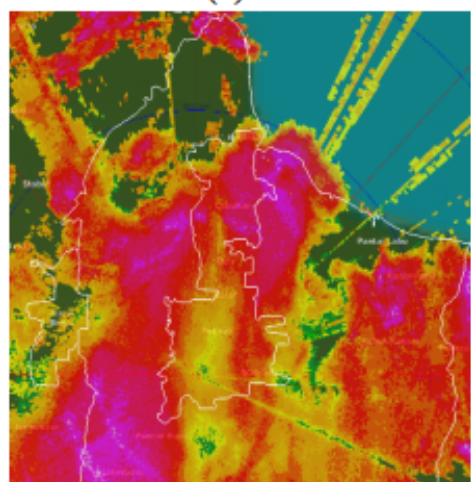

(d)

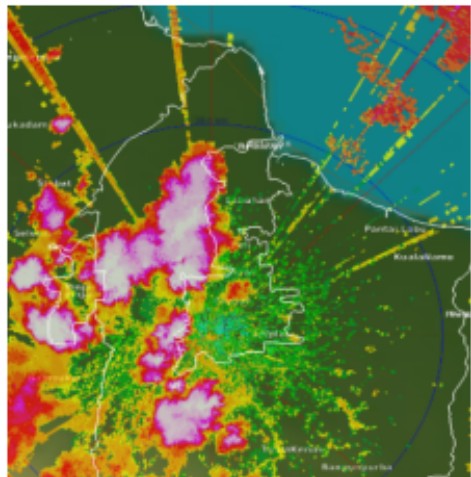

(b)

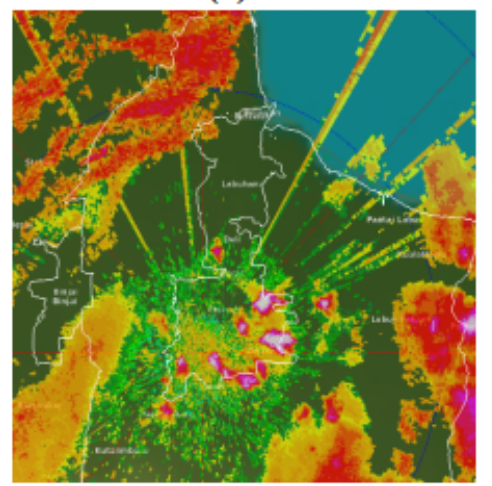

(e)

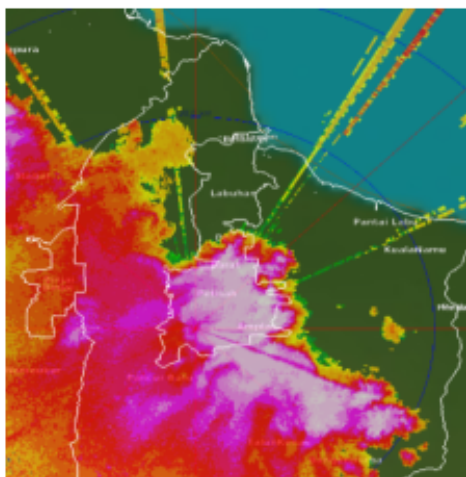

(c)

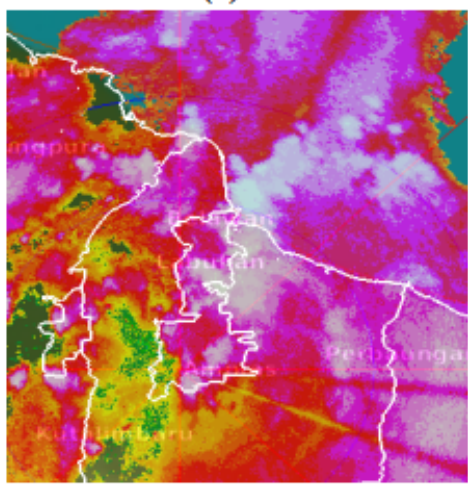

(f)

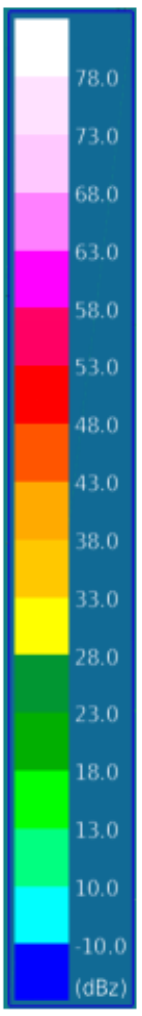

Gambar 3: Hasil Produk VIR pada pukul (a) 12.30 WIB, (b) 13.30 WIB, (c) 15.00 WIB, (d) 17.00 WIB, (e) 18.10 WIB, dan (f) $22.00 \mathrm{WIB}$.

reflektivitas 28-53 dBZ pada pukul 22.10 WIB. Nilai reflektivitas signifikan tidak terjadi lagi akan tetapi keseluruhan Kota Medan ditutupi dengan nilai reflektivitas 13-33 dBZ yang berlangsung hingga dini hari yaitu pukul 03.00 WIB tanggal 6 Oktober 2018. Setelah itu, tidak terdapat lagi sel-sel dengan nilai reflektivitas signifikan hingga pagi hari pukul 06.00 WIB.

\section{Analisis hasil produk radar VIR}

Hasil Produk VIL menunjukkan kandungan massa air di atmosfer yang cukup signifikan (dengan nilai 58-78 dBZ) terdapat di Kabupaten Deli Serdang (Barat Laut Medan) pada pukul 12.30 WIB (Gambar 3(a)). Kolom massa air tersebut semakin meluas dan berkembang di perbatasan Kabupaten Deli Serdang, Sebelah Barat Kota Medan pada pukul 13.30 WIB (Gambar 3(b)). Massa air tersebut semakin meluas dan bergerak ke arah timur sehingga memasuki wilayah Kota Medan meliputi wilayah Medan Bagian Barat dan sebagian Medan Bagian Selatan yaitu kecamatan Medan Tuntungan pada pukul 14.00 WIB. Aktivitas massa air tersebut masih terus berkembang sehingga memenuhi setengah Kota Medan pada pukul 15.00 WIB (Gambar 3(c)). Massa air signifikan tersebut masih terus berkembang sehingga memenuhi sebagian besar wilayah Kota Medan hingga pukul 15.30 WIB.

Kandungan massa air di Kota Medan pada pukul 16.00 WIB mulai berkurang, umumnya bernilai $38-48 \mathrm{dBZ}$ yang menutupi hampir keseluruhan Kota Medan. Kandungan massa air $>50 \mathrm{dBZ}$ hanya meliputi sebagian wilayah Medan Bagian Utara dan berpindah-pindah wilayah seiring bertambahnya waktu di sebagian Kota Medan hingga pukul 17.00 WIB (Gambar 3(d)). Kandungan massa air terus menurun yang ditunjukkan dengan nilai VIR di Kota Medan hanya berkisar $1023 \mathrm{dBZ}$ dari pukul 17.10 WIB. Penurunan aktivitas massa air pada pukul 17.10 WIB hanya berlangsung sementara. Massa air signifikan bermunculan kembali di bebarapa titik seperti Medan Kota, Medan Denai, Medan Perjuangan, Medan Johor, dan Medan Maimun pada pukul 18.10 WIB (Gambar 3(e)). Massa air tersebut terus berkembang yang terpusat di wilayah Medan Bagian Tengah pada pukul 19.00 WIB dan bergerak ke arah Utara sehingga memenuhi sebagian besar wilayah Kota Medan Bagian Utara hingga pukul 20.00 WIB. Setelah itu aktivitas massa air kembali menunjukkan penurunan.

Aktivitas massa air menunjukkan perubahan yang relatif cepat. Aktivitas massa air yang menurun kemudian menunjukkan kenaikan kembali satu jam kemudian yaitu pada pukul 21.20 WIB di wilayah Medan Bagian Utara. Peningkatan massa air terjadi cukup cepat sehingga massa air signifikan menutupi hampir seluruh Kota Medan pada pukul 22.00 (Gambar 3(f)). Hal tersebut berlangsung hingga dini hari yaitu pukul 00.10 WIB tanggal 6 Oktober 2018. Kota Medan masih tertutupi massa air yang cukup tinggi tapi tidak 


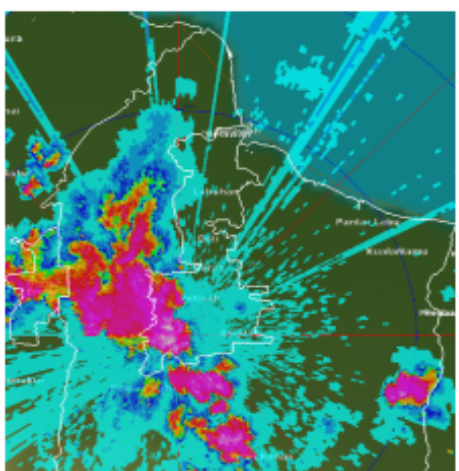

(a)

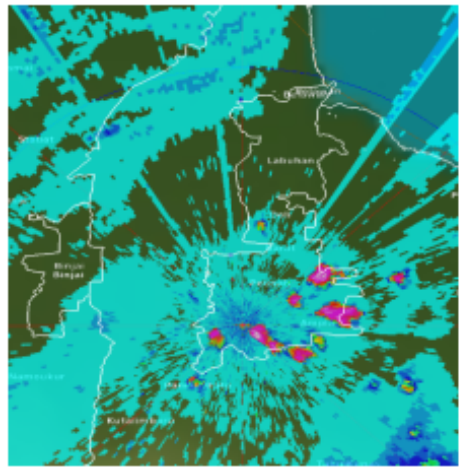

(d)

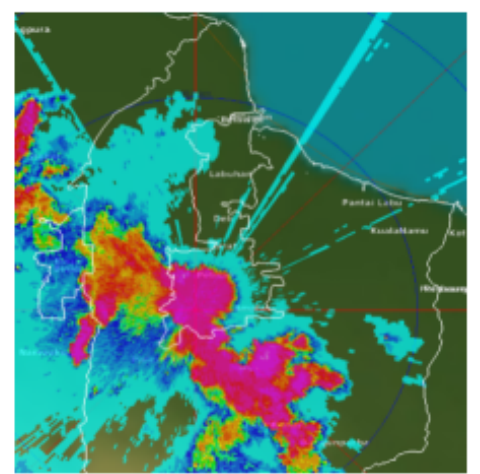

(b)

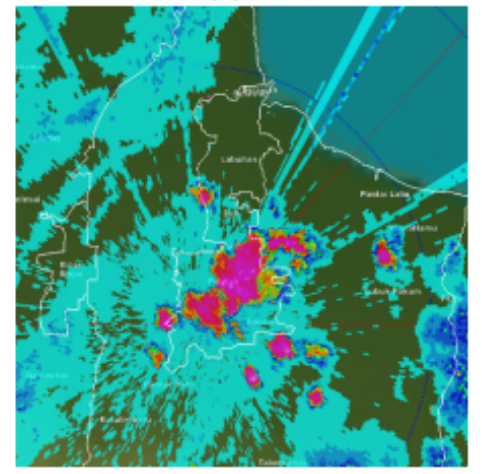

(e)

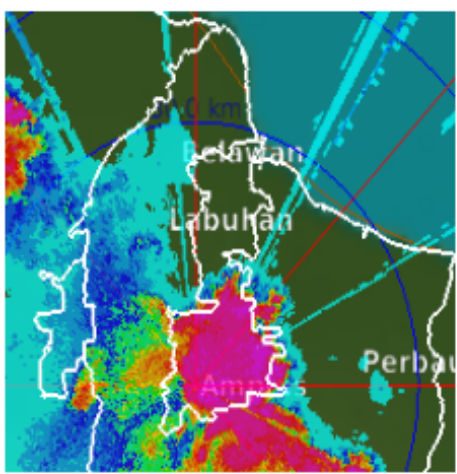

(c)

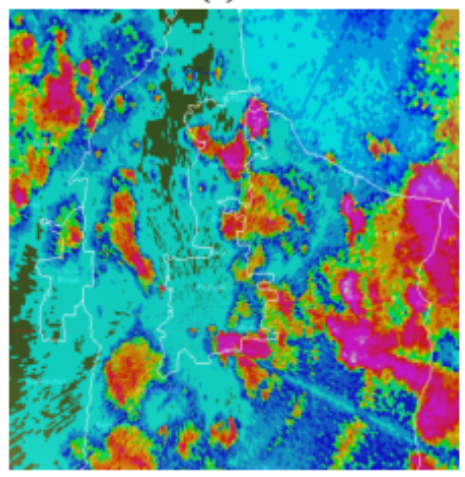

(f)

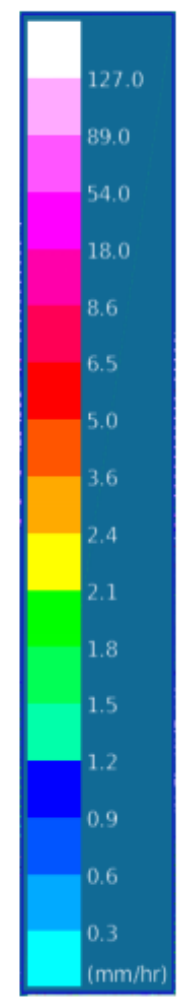

Gambar 4: Hasil Produk CMAX momen intensitas curah hujan rata-rata pada pukul (a) $14.00 \mathrm{WIB}$, (b) $14.30 \mathrm{WIB}$, (c) 15.00 WIB, (d) 18.10 WIB, (e) $18.30 \mathrm{WIB}$, dan (f) 21.10 WIB.

terlalu signifikan (berkisar antara 48-53 dBZ) hingga pukul 01.30 WIB. Sama seperti proses sebelumnya, aktivitas massa air signifikan mengalami penurunan beberapa saat dan kemudian meningkat kembali pada pukul $02.00 \mathrm{WIB}$ dan terus meluas hingga pukul 03.00 WIB. Setelah itu, aktivitas massa air signifikan semakin berkurang dan menghilang hingga pagi hari.

\section{Analisis produk curah hujan hasil Radar}

Radar cuaca mampu mengkonversi nilai reflektivitas menjadi curah hujan dalam satuan $\mathrm{mm} / \mathrm{jam}$, baik secara spasial maupun temporal. Secara spasial, wilayah Medan Marelan terlebih dahulu mengalami hujan dengan intensitas 8 hingga $18 \mathrm{~mm} / \mathrm{jam}$ terjadi pada pukul 13.00 WIB. Seperti diketahui sebelumnya bahwa terdapat kandungan massa air signifikan yang berasal dari Kabupaten Deli Serdang, Barat Laut Medan yang bergerak masuk ke wilayah Medan Bagian Utara yaitu Kecamatan Medan Marelan. Potensi hujan tersebut semakin meluas di wilayah perbatasan antara Deli Serdang dan sebelah Barat Kota Medan yang meliputi kecamatan Medan Marelan, Medan Deli, Medan Helvetia, dan Medan Barat dalam setengah jam berikutnya.

Wilayah potensi hujan sedang hingga lebat $(8-60 \mathrm{~mm} / \mathrm{jam})$ berpindah ke wilayah Medan Bagian Barat pada pukul 14.00 WIB (Gambar 4(a)). Wilayah yang mengalami potensi hujan semakin meluas hingga meliputi sebagian Medan Bagian Selatan dan Timur yaitu Kecamatan Medan Tuntungan, Medan
Johor, Medan Polonia, dan Medan Maimun pada pukul 14.30 WIB (Gambar 4(b)). Tiga puluh menit berikutnya (15.00 WIB), seluruh wilayah selatan Kota Medan meliputi Medan Bagian Barat, Timur, Selatan, dan Tengah, mengalami hujan ringan-sedang (Gambar 4(c)). Potensi hujan semakin berkurang dan beberapa wilayah di Kota Medan hanya mengalami hujan dengan intensitas ringan-sedang (3-15 mm/jam) pada pukul 16.30 WIB.

Hujan di Kota Medan mereda selama kurang lebih 90 menit hingga pukul 18.00 WIB. Hujan dengan intensitas sedanglebat terpantau kembali terjadi pada pukul 18.10 WIB di beberapa titik wilayah Kota Medan yaitu: Medan Kota, Medan Denai, Medan Perjuangan, Medan Johor, dan Medan Maimun (Gambar 4(d)). Potensi hujan yang terjadi meluas meliputi beberapa kecamatan di Medan Bagian Tengah, Timur, dan Barat pada pukul 18.30 WIB (Gambar 4(e)). Seiring pertambahan waktu, potensi hujan ringan-sedang berpindah dari Medan Bagian Selatan menuju ke arah utara mencakup wilayah Medan Bagian Tengah pada pukul 19.00 WIB kemudian meliputi Medan Bagian Utara yaitu Medan Marelan dan Medan Belawan pada pukul 19.30 WIB. Potensi hujan di Kota Medan kembali menghilang sesaat hingga kemudian beberapa wilayah yang terkena hujan pada pukul 21.10 WIB yaitu kecamatan Medan Labuhan, Medan Johor, dan Medan Deli (Gambar 4(f)). Hujan dengan intensitas ringan hingga sedang dengan durasi singkat (sekitar 20 menit) sempat terjadi di beberapa kecamatan dari pukul 22.00-22.20 WIB. Setelah itu, 


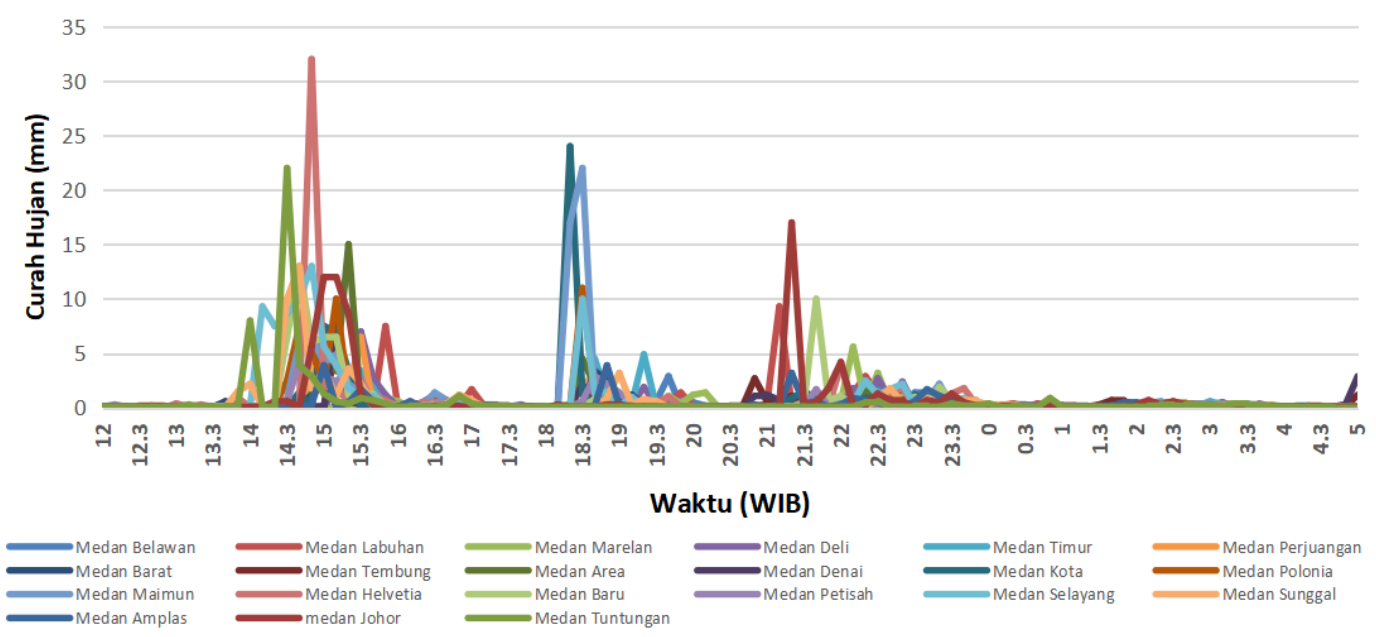

Gambar 5: Grafik curah hujan tanggal 5 Oktober 2018 di tiap kecamatan Kota Medan.

Kota Medan umumnya hanya mengalami hujan dengan intensitas ringan yang terjadi hingga dini hari.

\section{Analisis hasil produk RHG}

Hasil RHG di tiap kecamatan Kota Medan menunjukkan bahwa pada tanggal 05 Oktober 2018, Kota Medan umumnya terkena hujan terbagi dalam tiga waktu. Hujan dengan intensitas paling tinggi terjadi pada siang hingga sore hari yaitu sekitar pukul 14.00-15.50 WIB. Pada periode ini, hampir semua kecamatan menunjukan curah hujan $>5 \mathrm{~mm}$. Kenaikan curah hujan tertinggi terjadi pada pukul 14.50 WIB di Kecamatan Medan Helvetia dengan intensitas $32 \mathrm{~mm}$. Curah hujan di Kecamatan Medan Tuntungan juga cukup tinggi dengan intensitas $22 \mathrm{~mm}$ yang terjadi 20 menit sebelumnya yaitu pada pukul 14.30 WIB (Gambar 5).

Hujan dengan intensitas $<1 \mathrm{~mm}$ sudah terjadi sejak pukul 13.00 WIB di Medan Helvetia dengan intensistas $0.4 \mathrm{~mm}$. Namun, hujan dengan intensitas $<1 \mathrm{~mm}$ pertama kali terjadi di Kecamatan Medan Sunggal pada pukul 13.50 WIB. Hujan kemudian semakin meluas dan berkembang sehingga mencakup hampir seluruh Wilayah Kecamatan Kota Medan. Seperti yang dibahas pada bab sebelumnya, Kandungan massa air dan tutupan awan-awan konvektif di Kota Medan terindikasi terjadi sekitar pukul 14.00 WIB. Potensi awan-awan konvektif tersebut terus berkembang dan meluas sehingga meliputi sebagian besar wilayah Kota Medan. Wilayah Kecamatan dengan peningkatan curah hujan yang cukup tinggi dapat disebabkan awan-awan konvektif mengalami fase matang di wilayah tersebut. Hujan dengan intensitas tinggi yang dapat disertai badai guntur dapat terjadi ketika Awan mengalami fase matang.

Periode hujan dengan intensitas tinggi yang kedua di Kota Medan umumnya terjadi pada petang yaitu sekitar pukul 18.20 19.40 WIB. Periode hujan kedua ini diawali dengan kemunculan hujan lebat secara mendadak pada pukul 18.20 WIB yang terjadi di Kecamatan Medan Kota dan Medan Medan Maimun. Curah hujan yang terjadi di Kecamatan Medan Kota tercatat sebanyak $24 \mathrm{~mm}$ yang merupakan tertinggi pada peri- ode kedua. Hujan di Kecamatan Medan Maimun sebenarnya merupakan yang tertinggi akibat hujan lebat yang terjadi selama 20 menit secara terus menerus. Tercatat curah hujan di Kecamatan Medan Maimun pada pukul 18.20 WIB yaitu 17 $\mathrm{mm}$ dan pukul 18.30 WIB yaitu $22 \mathrm{~mm}$ sehingga curah hujan yang diperoleh dalam 20 menit sebanyak $39 \mathrm{~mm}$. Hujan yang terjadi setelah pukul 18.30-20.00 WIB bersifat merata dengan intensitas ringan yang terjadi di hampir semua Kecamtan Kota Medan.

Hujan lebat secara mendadak yang terjadi di kedua Kecamatan tersebut mengidentifikasikan bahwa terdapat pertumbuhan sel-sel awan konvektif yang cukup signifikan terjadi di kedua wilayah tersebut. Seperti dijelaskan sebelumnya bahwa terdapat pertumbuhan sel awan yang cukup signifikan pada pukul 18.10 WIB di beberapa titik di Wilayah Kota Medan. Sel tersebut kemudian meluas dan berkembang sehingga menutupi sebagian besar wilayah Medan Bagian Timur. Tutupan awan dan kandungan massa air pada pukul 18.20 WIB di kedua kecamatan tersebut terlihat sangat signifikan. Hal ini yang mungkin dapat mengakibatkan hujan di kedua kecamatan tersebut tinggi.

Periode hujan dengan intensitas tinggi yang ketiga di Kota Medan umumnya terjadi pada malam hari yaitu sekitar pukul 21.10-23.40 WIB. Puncak curah hujan tertinggi pada periode ini terjadi di Kecamatan Medan Johor dengan intensitas $17 \mathrm{~mm}$ pada pukul 21.20 WIB. Curah hujan di Kecamatan Medan Johor pada saat itu naik dengan sangat cepat. Tercatat hanya dalam 10 menit curah hujan meningkat hingga $17 \mathrm{~mm}$. Setelah itu, curah hujan kembali turun dengan cepat menjadi $0.3 \mathrm{~mm}$ pada pukul 21.30 WIB. Curah hujan Kecamatan Medan Labuhan terlebih dahulu terjadi hujan dengan intensitas tinggi yaitu 9,3 mm pada pukul 21.10 WIB. Kemudian Kecamatan Medan Baru juga dilanda hujan dengan intensitas tinggi pad pukul 21.40 WIB dengan intensitas 10 $\mathrm{mm}$ dan Medan mareda dengan intensitas 5,6 $\mathrm{mm}$ pada pukul 22.10 WIB.

Fluktuasi curah hujan relatif lebih rendah dibandingkan dua periode curah hujan sebelumnya. Hujan yang terjadi umum- 
nya memiliki intensitas ringan akan tetapi memiliki durasi yang relatif lebih lama. Kriteria hujan tersebut umumnya berasal dari awa-awan yang bersifat stratus (menyebar) dan merata menutupi suatu wilayah.

\section{SIMPULAN}

Radar cuaca sangat handal dipakai dalam menganalisis kondisi cuaca yang fluktuatif dalam skala lokal (kecamatan) dan durasi singkat saat kejadian banjir akibat curah hujan tinggi di Kota Medan pada tanggal 05 Oktober 2018. Curah hujan dengan intensitas tinggi yang terjadi di Kota Medan pada tanggal 5 Oktober 2018 umumnya terbagi menjadi tiga periode yaitu hujan pada siang hingga sore (pukul 14.00-15.50 WIB), pada petang (18.20-19.40 WIB), dan hujan pada malam hari (21.10-23.40 WIB). Fluktuasi curah hujan tertinggi pada periode pertama terjadi di kecamatan Medan Helvetia dengan kenaikan curah hujan sebanyak $32 \mathrm{~mm}$ dalam 10 menit yang terjadi pada pukul 14.50 , pada periode kedua terjadi di kecamatan Medan Kota dengan kenaikan 24mm pada pukul 18.20 WIB, dan periode ketiga terjadi di kecamatan Medan Johor dengan kenaikan $17 \mathrm{~mm}$ pada pukul 21.20 WIB.

\section{Ucapan Terima Kasih}

Penulis mengucapkan terima kasih kepada Balai Besar Meteorologi Klimatologi dan Geofisika Wilayah I Medan yang telah mendukung penelitian ini dengan memberikan data Radar Cuaca EEC dan pengolahannya menggunakan perangkat lunak EDGE.
[1] Badan Nasional Penanggulangan Bencana (BNPB), "Data informasi Bencana Indonesia (Dibi)", di akses di web http://bnpb.cloud/dibi/beranda, (2018).

[2] Badan Meteorologi Klimatologi dan Geofisika (BMKG), Keputusan 009 tahun 2010, "Prosedur Standar Operasional Pelaksanaan Peringatan Dini dan Diseminasi Informasi Cuaca Ekstrem", 2010.

[3] J.A.I. Paski, D.S. Permana, S. Sepriando, D.A.S. Pertiwi, "Analisis Dinamika Atmosfer Kejadian Hujan Es Memanfaatkan Citra Radar dan Satelit Himawari-8 (Studi Kasus : Tanggal 03 Mei 2017 di Kota Bandung)", Seminar Nasional Penginderaan Jauh ke-4, Depok, 2017.

[4] S. Fitria, "Teknik Interpretasi dan Analisa Citra Radar untuk Pemberian Informasi yang Lebih Baik", Prosiding Workshop Operasional Radar Cuaca, vol. I, Januari 2016.

[5] B.D. Finnerty, M.B. Smith, D.J. Seo, V. Koren, G.E. Moglen, "Space-time scale sensitivity of the Sacramento model to Radar-gage precipitation inputs”, J. Hydrol., vol. 203, pp. 2138, 1997.

[6] S. Yoon, C, Jeong, and T. Lee, "Flood Flow Simulation Using CMAX Radar Rainfall Estimate in Orographic Basin", Meteorol. Appl., vol. 21, pp. 596-604, 2014.

[7] Noersomadi, $d k k$., "Pengamatan Awan dan Variasi Cuaca Harian Menggunakan Transportable X-Band Radar", Seminar sains atmosfer, LAPAN, Jakarta, 2013.

[8] T. Sinatra, dan Noersomadi, "Pemanfaatan Transportable Radar Cuaca Doppler X-Band Untuk Pengamatan Awan", Berita
Dirgantara, vol. 16, no. 2, hlm. 91-97, Desember 2015.

[9] A. Kristianto, I.J.A. Saragih, G. Larasati, dan K. Akib, ”Identifikasi Kejadian Hujan ES Menggunakan Citra Radar dan Satelit Cuaca”, Prosiding PIT ke-5 Riset Kebencanaan IABI, Universitas Andalas, Padang, 2-4 Mei 2018.

[10] J.A.I. Paski, dan D.S. Permana, "Using the C-Band Doppler Weather Radar Data to Reconstruct Extreme Rainfall Event on 11th March 2018 in Bangka Islan, Indonesia", MATEC Web of Conference, 229, 04013, 2018.

[11] Samriyanto, "Analisis Citra Satelit dan Radar untuk Membuat Prediksi Cuaca Ekstrim”, Buletin BMKG, vol. 6, no. 4, 2010.

[12] E. Wardoyo, "Analisis Interfensi Frekuensi Radar Cuaca CBand di Indonesia", IncomTech, Jurnal Telekomunikasi dan Komputer, vol.5, no.2, hln. 163-184, Mei 2014.

[13] M.A. Massinai, "Analisis Liputan Awan Berdasarkan Citra Satelit Penginderaan Jauh", Pertemuan Ilmiah Tahunan MAPIN XIV, "Pemanfaatan efektif penginderaan jauh untuk peningkatan Kesejahteraan Bangsa", Surabaya, 2005.

[14] Badan Pusat Statistik (BPS) Kota Medan, "Bagian tata Pemerintahan, 2-15", Medan kota.bps.go.id. Diakses 18 November 2018

[15] Pemkot Medan, "Laporan Akuntabilitas Kinerja Instansi Pemerintah (LAKIP) Kota Medan T.A. 2012".

[16] Wikipedia, Lokasi Kota Medan doi Provinsi Sumatera Utara. Dibuat oleh Ewesewes di Wikipedia Bahasa Bahasa Indonesia, Diakses 18 November 2010 